\title{
Torture and Absolution: The Shadow Twin Towers of Atro/City
}

\author{
Cynthia Haynes
}

\begin{abstract}
Tentacles are always moving, changing direction, twisting, flowing, twitching, frictionless, striated, anti-gravitational, elusive, searching, wanting, feeling, grasping, entrapping. They are magnitudes of intensity, unconscious but alive. ... [Tentacles] map the terrain of the invisible, anticipating all possible encounters while seeming to be randomly writhing .... but even in this state of focus, tentacles cannot help but engage in apparently unnecessary, decadent behavior. This is because they are already anticipating the contingencies of their next encounter .... The violence of the encounter does not erase distinction between forms, but grafts impulses or sensibilities of one onto the other. Such a tactile morphology of both sensing (a desire for information) and grasping (an exchange between identities) refigures differences in terms of sublimation. (Wiscombe 1998).
\end{abstract}

\section{North Tower}

The war on terror extends beyond the geopolitical borders of Iraq, Afghanistan, and other nations that support and harbor terrorists. It depends on its own vast network of what the Bush administration variously calls a "coalition of the willing." Of what they are willing to do and to permit is called into question in this section on the North Tower, which interrogates the practices of interrogation upon which the clandestine policy of 'extraordinary rendition' is based. In contradistinction to 'cities of refuge' that harbor refugees from terror, 'cities of rendition' harbor detainees in U.S. custody who have been transported to a 'friendly government' where extrajudicial interrogation techniques fly under the radar of international law and are in reality nothing more than 'torture by proxy.' Such cities are often de-facto cities only insofar as they are temporary places for detention and interrogation (e.g., airplanes, airports, camps). They are, nevertheless, rendered cities rhetorically (in memos and patriot acts) by governments who prefer to question individuals outside the jurisdiction of federal and international courts.

I have on my radar two planes bound for cities of rendition. We all know the torture that happened inside four commercial airliners on 9/11. But not so many of us know what happened inside the Gulfstream V aircraft, N379P. It is probably safe to say that everyone is interested in saving lives. But it is not safe to say that in order to save lives some of us may feel it is sometimes necessary to torture someone. I am tempted to ask my readers to put your hands behind your back and clasp your wrists and hold that position throughout your reading. I do not want to 'see' the hands you use to write, the ones you use to grade student writing, those hands that sign the ledgers of literacy that litter this country. I will not, however, ask that of you. I will simply pretend that your hands are tied. I am also pretending that you are sitting on the edge of your seat. That you are bound up, not spell-bound. I want you a little off-balance. I want us all to understand what it is like to undergo 'enhanced interrogation.' And I want us all a bit worried and unsteady, precariously perched upon an 'extrajudicial edge,' not lounging in our ample academic seats.

My pretend game also includes imagining my readers in some restaurant, or hotel meeting room, a room fortuitously named for the City of Versailles. For the moment, the year is 1793. Louis XVI has been condemned to die, and the Committee of Public Safety is just formed. Versailles was called at that time the 'cradle of liberty', but today we know this period in its history as the beginning of the Reign of Terror. (Of, interest, perhaps, is the fact that Washington, D.C. was designed by the same French architect who designed the city of Versailles.) And I leave it to your imagination to render the parallels I infer. Now that the interrogation stage is set, we will do a bit of a 
revisionist remix and imagine Versailles as a city that in the torture trade is sometimes called a 'black site,' a place of 'extraordinary rendition,' that euphemism for torture by proxy. In what follows, you will read a series of performative questions and coerced answers by some high profile 'ghost detainees.' Unlike enhanced interrogations, however, this focus group may actually yield some valuable information, rather than the kind of information that anyone in enough pain will tell you eventually, that all of us would gladly divulge to save ourselves.

Another French architect, not one by trade, but one that de-structured all structuration, and one whose specter haunts the walls of this imaginary city, will now lead with the first confession in this mock interrogation. Let us imagine that Jacques Derrida, hands also forming a chiasmus behind his back, answered 'without alibi':

It is necessary to save, it is necessary to assure salvation... [ [and] this salutary, sanitary, or immunitary concern triggers simultaneously a gesture of war: the militant would like to cure or save by routing, precisely, a resistance. I am not sure that this rescue project, this salvation or health plan, this profession of public safety is not also, in part, or even in secret, that of your States General, which is already pregnant, virtually, in the dark, with some shadow Committee of Public Safety. As a result, I am not sure, at this point, that I am altogether one of you even if, in part, I remain proud to claim to be by sharing your worry. (Derrida 2002: 243)

What concerns Derrida is the relation between cruelty and sovereignty. The revolution in principle (concerning princes) begat a "cruel Terror" (Derrida 2002:260). As Derrida formulates the question and then answers it: Was the convocation of the States General, convoked by a king, the first gesture of cruelty, or a vain attempt to prevent it (Derrida 2002: 260)?

We will never know. By definition, we will never know whether the States General, at the moment of their first convocation, were destined to condemn or save the king's head, and it matters little, no doubt, because in any case the two gestures, condemning and saving, remain indissociable. They inscribe in the concepts of sovereignty and cruelty an ambiguity that is as unrelievable as autoimmunity itself. It is too late, even for the question. (Derrida 2002: 260).

Right. Mortal questions are always too late. According to Thomas Nagel, "[n]o elaborate moral theory is required to account for what is wrong in cases like the Mylai massacre, since it did not serve, and was not intended to serve, any strategic purpose .... I propose to discuss the most general moral problem raised by the conduct of warfare: the problem of means and ends" (Nagel [1971] 1979:53-54). Atrocities committed in the name of warfare also spotlight cities of extraordinary rendition, the atrocious having roots in the Greek for 'black eye.' Certainly the United States suffers a perpetual black eye since the Mylai massacre, and it grows blacker by the minute given the events at Abu Ghraib, and God knows where and what else (and He does). In short, enhanced interrogration and/as extraordinary rendition reinvents the city as atrocity — atrocities that figure as atro-tropaic events-black tropes writing black sites. A memo, full of black tropes, can function as architecturally as blueprints for a municipality. It can provide legal and extra/ordinary powers (sometimes called eminent domain), and we should not neglect the less than benign relation between ordinary and ordnance, nor between municipality and munitions. Cities of rendition give the space of such encounters, and writing gives the order. John Yoo, legal architect of the Bush administration defense of the use of enhanced interrogation techniques, wrote such a memo one week before the U.S. invasion of Iraq in March 2003. According to a CNN report:

The memo also includes past legal defenses of interrogations that Yoo wrote are not considered torture, such as sleep depravation, hooding detainees and 'frog crouching,' which forces prisoners to crouch while standing on the tips of their toes. 'This standard permits some physical contact,' the memo said. 'Employing a shove or slap as part of an interrogation would not run afoul of this standard.' (CNN 2008)

Here we can see the 'tactile morphology of tentacles' already "anticipating the contingencies of their next encounter" (Wiscombe 1998: 25\%). It seems the standards for treatment of prisoners of war, established by obscure bodies such as the Geneva Convention, are full of restrictions that now require rhetorical rerouting. As Eyal Weizman explains, "Since military planners are acutely aware that the methods required for urban warfare will make soldiers potentially liable to prosecution for war crimes, American and Israeli governments cancelled their membership in the ICC [International Criminal Court]" (Weizman 2003:180). In addition, the Bush administration has aggressively sought to weaken the Court's effectiveness by "negotiating bilateral agreements with other countries, insuring immunity of U.S. nationals from prosecution by the Court. As leverage, Washington threatened termination of economic aid, withdrawal of military assistance, and other painful measures" (Global Policy Forum 2008).

There are, however, powerful correctives at work to offset such political end runs. Weizman points to the 
existence of international courts, the development of cheap recording equipment, and the availability of satellite communication that greatly limit military operational methods (2003). The Army of One, however, highlights a radical singularity that is proving to be a motto forged from a two-edged sword. The military term " "strategic corporal' characterizes the huge ramifications of the actions of the individual soldier" (Weizman 2003:180). One soldier, a graduate student in Clemson University's M.A. in Professional Communication program, recently told me why a $\$ 200$ light kit would achieve the same effect as more 'enhanced interrogation' techniques. I asked how that is possible? He said, "Those lights are hot, and you can't see your interrogator. It's like having God asking you questions, and God wouldn't ask you trivial questions, right?" (Callot 2008). I asked him whether he had ever participated in questionable interrogations, and he said on a few occasions it was critical enough to use enhanced interrogation techniques, but instead they used a "modified civil affairs operation" (Callot 2008). At the end of my interview with him, I thanked him for sharing his experiences and opinions with me, and his parting comment was: "Listen, I'm just one soldier. There are about a million of us" (Callot 2008).

And, as we all know, other operatives serving our country also conduct enhanced interrogations. Thus, we should observe a snippet of the recent Senate Select Intelligence Committee interrogation of CIA Director (and Air Force General) Michael Hayden on the question of enhanced interrogation techniques.

[Senator] FEINSTEIN: I'd like to ask this question: Who carries out these [enhanced interrogation] techniques? Are they government employees or contractors?

HAYDEN: At our facilities during this, we have a mix of both government employees and contractors. Everything is done under, as we've talked before, ma'am, under my authority and the authority of the agency. But the people at the locations are frequently a mix of both-we call them blue badgers and green badgers .... This is not where we would turn to Firm X, $\mathrm{Y}$ or $\mathrm{Z}$, and say, this is what we would like you to accomplish. Go achieve that for us and come back when you're done. That is not what this is. This is a governmental activity under governmental direction and control, in which the participants may be both government employees and contractors, but it's not outsourced.

[Senator] FEINSTEIN: I understand that.

HAYDEN: OK. Good. (Schachtman 2008)

As sometimes occurs during interrogations, the detainee reverses the roles and tries to wrest control of the process in order to have the last word. So, we sometimes see a good cop/bad cop interrogation method rhetorically defused in two words. "OK. Good." It's a political nightmare from which we desperately need to awaken. Simon Critchley, has a question for us: "My question is very simple, but the answer is far from self-evident: how do we begin to grasp the political situation in which we find ourselves? .... [more precisely, he asks] how did Bush get reelected in the American Presidential elections in November 2004? How did Bush win? Well, I think part of the story is that certain people in the Bush administration have got a clear, robust and powerful understanding of the nature of the political. They have read their Machiavelli, their Hobbes, their Leo Strauss and misread their Nietzsche" (Critchley 2007:133). "Politics is not the naked operation of power or an ethics-free agonism, it is an ethical practice that is driven by a response to situated injustices and wrong" (Critchley 2007:132). The problem is that injustices are sometimes situated outside the jurisdiction of victimary logic, and in fact exploit such logic to foster fear and thereby gain mass solidarity, whole choirs of solidarity singing in unison in the voting booths across this nation. Shades of the anti-civil rights racist election noise are lurking in the shadow of the symbolic, and criminal, twin towers of torture and absolution. "It seems that all the world is turning to noise. We need to turn up the signal, wipe out the noise" (Gabriel 2002).

\section{South Tower}

In case you haven't noticed, Retro is in style. Quite trendy, in fact. All the rage. So it seems altogether fitting to begin this shift from torture to absolution with a retro-spective moment from the 70s. For those of you who do not remember the 70s (and for some of us that decade is a bit of a blur), or those of you who were born in the post-70s era, let me simply plead guilty to committing what Douglas Coupland calls "legislated nostalgia," "to force a body of people to have memories they do not actually possess" (1991:41). But whether blurred or legislated, it is worth remembering the year 1972. I was enrolled in a community college where racial scuffles and student protests meant I could cut biology class and hone my ping pong skills in the student union, or find a private nook in the library 
to read D.H. Lawrence. When Coupland's Generation X-ers visit the Vietnam memorial, they capture this kind of "historical slumming" like this:

Andy, I don't get it. I mean, this is a cool enough place and all, but why should you be interested in Vietnam. It was over before you'd even reached puberty." "I'm hardly an expert on the subject, Tyler, but I do remember a bit of it. Faint stuff: black-andwhite TV stuff. Growing up, Vietnam was a background color in life, like red or blue or gold-it tinted everything. And then suddenly one day it just disappeared. Imagine that one morning you woke up and suddenly the color green had vanished, I come here to see a color I can't see anywhere else any more. (1991: 151)

So, picture the color green, and imagine the soundtrack of life in 1972 during this rundown of just some of the events of that year (Wikipedia).

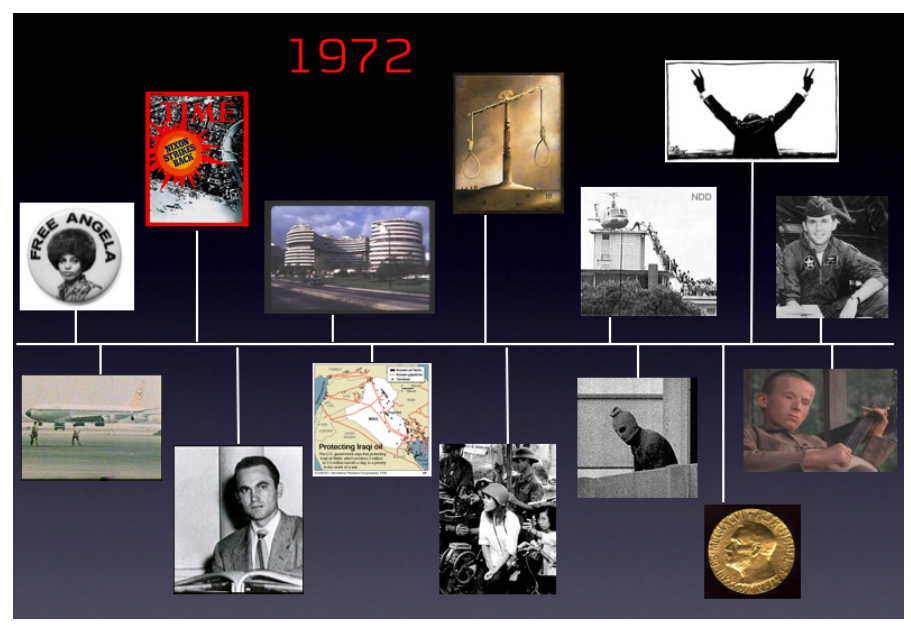

Visual Timeline of events in 1972 created by Cynthia Haynes

Angela Davis is released from jail. A Lufthansa plane is hijacked. President Nixon orders the mining of Haiphong Harbor in Vietnam. Governor George Wallace is shot. Watergate. Iraq nationalizes the Iraq Petroleum Company. The Supreme Court rules that the death penalty is unconstitutional. Jane Fonda tours North Vietnam. The last U.S. ground troops are withdrawn from Vietnam. The Munich Massacre of 11 Israeli athletes at the Summer Olympics shocks the world. In the Presidential election, Republican incumbent Richard Nixon defeats George McGovern in a landslide. There was no Nobel Peace Prize awarded in 1972. In 1972 George W. Bush refused to take the Air force physical exam, some claim because of their newly announced drug testing program. And, in 1972 the film Deliverance was released.

The rhetorical canon of delivery bears two connections here. First, the Greek term for delivery was 'hypokrisis,' which means 'acting.' Second, among its numerous definitions, delivery also means absolution. In 1637 Ben Jonson wrote: "Some language is high and great ... the composition full, the absolution plenteous, and poured out, all grave, sinewy, and strong” (qtd in OED; Discoveries Wks. 1846, 759). Although this is one of the more obscure meanings of absolution, I am asking delivery to function here as a rhetorical threshold, or what Brenda Laurel would term a "thresholdy phenomenon" (1991: 21). I want it to work out of obscurity, that which is shrouded or hidden in darkness, because not only does rhetoric sanction the notion of the hidden hermeneutic, it has wired (and worn) this switchplate as perhaps its only badge of responsibility. Heraclitus imagined the logos as lightning, the word as teleporting in and out of obscurity. Plato, as we know, deplored rhetoric's stormy personality, demanding that philosophy must tame this tempest and divest it of its mysterious powers. Of course, the irony is that philosophy plots its own storm paths using the same rhetorical radar, and then claims it has harnessed its energy for the "good," and constructs a political powerplant called democracy on the shores of the enlightenment ideals of reason, responsibility, and human rights. Yet democracy has suffered countless blackouts over the years. It has yet to figure out that is it not immune to power outages. It deplores the rhetorical rogue at the same time it sanctions the obscurity of the rogue, its ability to fly under the radar of the laws of nature and culture. This is how the 'hypokrisis' became the hypocrite- how delivery became deliverance, and how absolution wrote the book on auto-immunity. 
Maybe this brand of rhetoric is more like White lightning. On August 16, 2006, President George W. Bush became the first president to pardon a cast member of the 1972 Academy Award-nominated movie "Deliverance" (DOJ). Randall Deal, an obscure actor who played a bit part in the film, was convicted in the early 60s for violating liquor laws, more commonly known as 'moonshining.' Among the 157 individuals pardoned by Bush to date, five have been convicted of crimes related to moonshining.'

As with all presidencies, Bush has pardoned his share of convicted criminals, or commuted their sentence (the annual Thanksgiving Turkey and Scooter Libbey come to mind), but the Bush absolution of Randall Deal is tame compared to the absolution deal cut in 2006 between Congress and the Executive and Judicial arms of our government. It goes by the name of The Military Commissions Act of 2006. Elizabeth Holtzman explains:

Thirty-two years ago, President Gerald Ford created a political firestorm by pardoning former President Richard Nixon of all crimes he may have committed in Watergate -- and lost his election as a result. Now, President Bush, to avoid a similar public outcry, is quietly trying to pardon himself of any crimes connected with the torture and mistreatment of U.S. detainees. The "pardon" is buried in Bush's proposed legislation to create a new kind of military tribunal for cases involving top al-Qaida operatives. The "pardon" provision has nothing to do with the tribunals. Instead, it guts the War Crimes Act of 1996, a federal law that makes it a crime, in some cases punishable by death, to mistreat detainees in violation of the Geneva Conventions and makes the new, weaker terms of the War Crimes Act retroactive to 9/11. Press accounts of the provision have described it as providing immunity for CIA interrogators. But its terms cover the president and other top officials because the act applies to any U.S. national. (2006)

In short, retro-activity is also in. While it is equally important to scrutinize the rhetorical stripping of habeas corpus rights of detainees, the definitions of enhanced interrogation this act spells out, the permission of secret trials, and the absence of the right to a speedy trial, I want to switch off the auto-focus and zoom in on this retroactive immunity. And from my admittedly feminist perspective, I can tell you it has the muscular tone of absolution on steroids.

The problem is not a new problem, but we can date its most recent iteration to the hijackings of $9 / 11$, which (it turns out) became a compound hijacking-and though it may be considered irreverent or unpatriotic to say this, much more was hijacked that day than four airplanes. Within hours of the horrendous events of $9 / 11$, the twin engines of rhetoric and democracy were hijacked as well, and we have witnessed the violent unfolding of this hijacking over the past seven years. The War on Terror is on auto-pilot. It has built in auto-assessment, auto-systemchecks (as opposed to a checks and balance system), and auto-absolution. It is absolutely auto-immune.

The question of responsibility is, unfortunately, a question that rhetoric is hardly in a position to answer. And even though the question is being asked more loudly, more frequently, and by more and more people, the fact remains that this seven-year war machine and political juggernaut has the whole world on the verge of a power outage of epic proportions. Because the economic and social disasters that it has caused cannot be undone with rhetoric, this is the first time I sense the powerlessness of rhetoric to effect such a mass change. This is the first time that rhetoric seems, to me, doomed. I feel like storming the cockpit, but the doors have been reinforced with fear and retributionist policies. How do we disengage this auto-pilot? Whose responsibility is it? Where is response ability?

Democracy is missing. It is no longer the most effective means of delivering freedom, protecting its citizens, or bringing about justice. It has probably succumbed to the Stockholm syndrome, that is, it has become emotionally attached to its abductors. Pathos has turned to mass pathology. The people elected this president not once, but twice. While there are bills in both the House and Senate designed to restore the ability to prosecute government officials, including those in the White House, for war crimes, both bills are stalled in subcommittees, and have been for over a year-locked in the church coffers of special interests, compassionate conservativism, and faith-based politics.

If not democracy, then what is its Other? Derrida has exposed the inextricable link between democracy and GrecoChristian theology insofar as he reminds us that "where the democratic realm becomes coextensive with the political, where the democratic realm becomes constitutive of the political realm precisely because of the indetermination and the 'freedom,' the 'free play,' of its concept, and where the democratic, [has] become consubstantially political in this Greco-Christian and globalatinizing tradition . . . the only and very few regimes . [unless I am mistaken]. . that do not present themselves as democratic are those with a theocractic Muslim government" (2005: 28). Without fear of retribution, Derrida nevertheless speaks up for "the right to speak without taking sides for democracy" (2005:41). As he rightly observes, waging a war against the "axis of evil," those "assassins of democracy," inevitably results in restrictions on our own freedoms and rights, and abuses of potential enemies all of which insures that democracy "must thus come to resemble these enemies, to corrupt itself and threaten itself in order to protect itself against their threats" (2005: 40). For Derrida, "[w] herever freedom is no longer determined as power, mastery, or force, or 
even as a faculty, as a possibility of the 'I can' . ., the evocation and evaluation of democracy as the power of the demos begins to tremble" (2005:40-41). He asks, "Is democracy that which assures the right to think and thus to act without it or against it? Yes or no?" (2005:41; emphasis mine).

Although I am suggesting that rhetoric has been hijacked, and that may infer that we are responsible to (perpetually) plan and carry out its rescue, this would not be a rhetorical move. Have we forgotten the failed attempts to rehabilitate it? Have we forgotten our addiction to self-empowerment? Have we forsaken Nietzsche's warning against ressentiment and reactionary behavior? Have we forgotten his lesson that "slave morality always first needs a hostile external” ([1887] 1969:37). Have we foolishly underestimated the genius in his anti-imperative testimony: “The last thing I should promise would be to 'improve' mankind” ([1888] 1969:217)? Is our anti-Nietzschean will-torehab the ultimate will-to-power? Are these the lessons unlearned from the textbook of our most pressing danger? That train left the station with Heidegger, who reminded us that:

What has long ... been threatening man with death, and indeed with the death of his own nature, is the unconditional
character of mere willing in the sense of purposeful self-assertion in everything. What threatens man in his very nature is
the willed view that man, by the peaceful release, transformation, storage, and channeling of the energies of physical nature,
could render the human condition, man's being, tolerable for everybody and happy in all respects. But the peace of this
peacefulness is merely the undisturbed continuing relentlessness of the fury of self-assertion which is resolutely self-reliant.
What threatens man in his very nature is the view that this imposition of production can be ventured without any danger, as
long as other interests besides - such as, perhaps, the interests of a faith-retain their currency. ([1946] 1977:117)

This passage contains a doubly hyphenated problematic in the same word: self-assertion and self-assertion. My narrative thus far is a cautionary tale of responsibility run amok amid the rhetorical sanction, or absolution, of its tragic consequences. It is perhaps utterly forgettable. In a Nietzschean sense, I hope it is. I hope we can forget the 'for' in whose name responsibility and democracy are most frequently invoked in order to take up Nietzsche's goal for mankind, which is primordially (in its itself-ness) Being's goal, to produce a being who can take absolute responsibility for himself. This is not to say it is 'against' those for whom we are responsible. As Derrida says, "[l]et us say yes to who or what turns up, before any determination, before any anticipation, before any identification, whether or not it has to do with a foreigner, an immigrant, an invited guest, or an expected visitor" (2000:77). But it merits our acknowledgement that the complicity of rhetoric in the compliance-gaining strategies of rogue responsibility is retroactively marked - it is being held hostage by the worst of both faith and reason. Doing something would, then, amount to actions that could not help but be a monstrous reflection of these twin extremisms. Such doing, in theological terms, is called auto-absolution. In political terms, it is called manifest destiny. In Kant's theory of justice, it is called retributivism.

Speaking "in the double wake of Nietzsche and Freud," (2002:271) Derrida relentlessly reminds us " of the indissociable tie between cruelty and state sovereignty, state violence, the state that, far from combating violence, monopolizes it" (2002: 268). Now, in addition to the spread of democracy, freedom, and free enterprise-by all accounts taking responsibility for the liberty and prosperity of all people-we take it upon ourselves to export and outsource retribution. Unfortunately, such taking has taken thousands of lives, yet the policy-makers of democratic ideals do not implement or articulate these policies without rhetorically fail-safe absolution imbedded in each 'mission accomplished' or each 'sacrifices will be made' passive prediction. There is, in other words, what Derrida calls an "autoimmune necessity inscribed right onto democracy" (2005:36). The task of rhetoric is to reveal its own autoimmunity and turn it back on itself ir/responsibly. Much as Derrida reformulated the 'autoimmune law' "around the community as auto-co-immunity" (2005:35), rhetoric's responsibility is 'to take absolute responsibility for itself' rather than to absolve itself 'for' the world. If Heidegger was right to say "Language is the House of Being" ([1946] 1977: 193), then rhetoric is not wrong to say to 'Mind your own house.'

\section{References}

1972. Wikipedia. en.wikipedia.org/wiki/1972. Accessed June 2, Butler, Judith, and Gayatri Chakravorty Spivak. 2007. Who Sings 2008. 
Callot, Sean. 2008. Personal Interview. March 24, 2008.

Coupland, Douglas. 1991. Generation X: Tales for an Accelerated Culture. New York: St. Martin's Press.

CNN. 2008. "Memo: Bush's Power Trumps Laws on Torture." Accessed June 28, 2008 (www.cnn.com/2008/US/04/01/ torture.memo.ap/index.html?iref=newssearch).

Critchley, Simon. 2007. Infinitely Demanding: Ethics of Commitment, Politics of Resistance. London: Verso.

Department of Justice. 2006. President George W. Bush Pardons Press Release. Accessed June 2, 2008 (www.usdoj.gov/opa/ pr/2006/August/06_opa_544.html).

Derrida, Jacques. 2000. Of Hospitality. Translated by Rachel Bowlby. Stanford: Stanford University Press.

----. 2005. Rogues: Two Essays on Reason. Translated by PascaleAnne Brault and Michael Naas. Stanford: Stanford University Press.

----. 2002. Without Alibi. Translated by Peggy Kamuf. Stanford: Stanford University Press.

Gabriel, Peter. 2002. “Signal to Noise.” Up. Virgin Records.

Global Policy Forum. 2008. "U.S. Opposition to the International Criminal Court” Accessed June 28, 2008 (www.globalpolicy. org/intljustice/icc/usindex.htm).

Heidegger, Martin. [1946] (1977). “Letter on Humanism." Martin Heidegger: Basic Writings. Edited by David Farrell Krell. New York: Harper and Row. 190-242.
----. 1971. Poetry, Language, Thought. Translated by Albert Hofstadter. New York: Harper and Row.

Holtzman, Elizabeth. 2006. "Bush Seeks Immunity for Violating War Crimes Act” Accessed June 2, 2008 (www.commondreams.org/views06/0923-22.htm).

Jonson. Ben. [1637] Discoveries Wks. 1846, 759. Oxford English Dictionary. Accessed June 2, 2008 (sys.lib.clemson.edu:2119/ cgi/entry/50000806? single $=1 \&$ query_type $=$ word \&queryword $=$ a bsolution \&first $=1 \&$ max_to_show $=10)$.

Laurel, Brenda. 1991. Computers as Theatre. Reading, MA: Addison-Wesley.

Nagel, Thomas. [1971] 1979. "War and Massacre." Pp. 53-74 in Mortal Questions. Cambridge: Cambridge University Press.

Nietzsche. Friedrich. [1887 and 1888] 1969. On the Genealogy of Morals and Ecce Homo. Translated by Walter Kaufmann and R. J. Hollingdale. New York: Vintage Books.

Shachtman, Noah. 2008. "Hayden Admits: Contractors Lead 'Enhanced Interrogations' at CIA Black Sites." WIRED Blog Network. Accessed June 28, 2008 (blog.wired.com/ defense/2008/02/in-testimony-be.html).

Weizman, Eyal. 2003. "Military Options as Human Planning." Interviewed by Philipp Misselwitz. Pp. 167-199 in Cities Without Citizens, edited by Eduardo Cadava and Aaron Levy. Philadelphia: Slought Books.

Wiscombe, Tom. 1998. "The Haptic Morphology of Tentacles." In Borderline, edited by Lebbeus Woords and Ekkehard Rehfeld. Vienna: Springer-Verlag. 25\%-31\%. 
